\title{
The Effect of Financial Flexibility on Financial Behavior of Companies Listed in Tehran Stock Exchange
}

\author{
Tahereh Alsadat Mirkhalili, Hamid Khajeh Mahmoudabadi* \\ Department of Financial Management, Yazd Branch, Islamic Azad University, Yazd, Iran \\ Email: *Khajeh.h@gmail.com
}

How to cite this paper: Mirkhalili, T.A. and Mahmoudabadi, H.K. (2018) The Effect of Financial Flexibility on Financial Behavior of Companies Listed in Tehran Stock Exchange. American Journal of Industrial and Business Management, 8, 143-155.

https://doi.org/10.4236/ajibm.2018.81009

Received: December 8, 2017

Accepted: January 19, 2018

Published: January 22, 2018

Copyright $\odot 2018$ by authors and Scientific Research Publishing Inc. This work is licensed under the Creative Commons Attribution International License (CC BY 4.0).

http://creativecommons.org/licenses/by/4.0/

\section{Abstract}

The flexibility plays an important role in making the managers powerful in the regard of investment in the future. The problems of the capital market have necessitated the maintenance of flexibility for the companies for the purpose of using profitable opportunities. The present research has aimed to study the effect of financial flexibility on the financial behavior. The statistic sample used in the present study consists of 100 companies accepted in Tehran stock exchange during the years 2009 to 2015. The financial flexibility and financial behavior are respectively the independent and dependent variables which were measured by the investment activity, dividend payout ratio, amount of cash holding and company value. The data analysis was done by the use of the multi-variable regression models based on the panel data techniques and the use of Eviews econometrics software. The results concluded from the study of effect of the financial flexibility on the financial behavior corresponding to the theoretical foundations which had meaningful and positive effects. Therefore, the hypothesis that the financial flexibility has positive and meaningful effects on the investment activity of the companies accepted in the stock exchange was confirmed. The other results of paper were that the financial flexibility had negative and meaningful effects on the dividend payout ratio. So, the hypothesis that the financial flexibility has negative and meaningful effects on the dividend payout ratio of the companies accepted in the stock exchange was not confirmed. The hypothesis that the financial flexibility has positive and meaningful effects on the amount of cash holding of the companies accepted in the stock exchange was not confirmed, because the effect of the flexibility on the amount of cash holding was not meaningful. Also, the hypothesis that the financial flexibility has positive and meaningful effects on the value of companies accepted in the 
stock exchange was confirmed.

\section{Keywords}

Financial Flexibility, Company Value, Investment Activity, Amount of Cash Holding, Dividend

\section{Introduction}

The financial flexibility is the affordance of companies for providing the financial recourses to have a proper reaction in the unexpected cases and events to maximize the company value [1]. Heath (1978) explains the financial flexibility as the power of corrective action for removing the cash paid being excess of the anticipated cash received with minimum effects on the present and future income or the market value of the company stock [2]. The companies with financial flexibility can stand against the financial pressures and when the profitable opportunity is achieved, they would provide the cash needed for the investment with minimum cost [3]. The companies with financial flexibility keep a reserved debt capacity for themselves in order to be able to apply more investment conservatism policy in the next years. The financial flexibility is a grade of capacity of one company so that it can equip its financial recourses in the regard of reactive activities to maximize the company value [4]. Gamba \& Triantis (2008), in their study for determining a model for the measurement of the financial flexibility, defined the financial flexibility as the capacity of one company to achieve and restructure its financing with the financing with lower cost. They express that the companies with financial flexibility can avoid the financial distress in the situation of negative shocks and they invest with low cost, when the profitable opportunities are increased [3]. The investment of the companies as the reproductive of cash flow plays an important role in the long-term performance, future value of companies and also the development of the countries. So, the recognition of the investment stimulus in the companies is very significant. The behavioral effect of the investors is based on the behavioral financial theory which interprets the deviation of the stock price from its intrinsic value. The behavioral financial is one of the important factors of the market deficiencies that focus on the systematic event of decision-making error of the investors and managers and surveys the manner in which the investors and managers make a systematic and intellectual error in their judgments [5]. The result of studies done by De Jong et al. (2012) revealed that one increase in the standard deviation of the financial flexibility would be resulted in the 5 percent increase of the future investments. The main purpose of this paper is the study of effect of the financial flexibility on the financial behavior in the companies accepted in Tehran stock exchange [6]. 


\section{Theoretical Foundations and Expansion of Research Hypotheses}

\subsection{Financial Flexibility}

The financial flexibility is the most important part of determination of structure of the company capital and can be applied to maintain the debt capacity for the purpose of future development of the company or minimizing the debts to avoid the financial distress in the economic recession. Also, the managers' demand for financial flexibility is the most important effective factor in the debt decisions of the companies [7]. The flexibility of the companies can be saved by the investment in the actual or financial assets. The financial flexibility can be very profitable for the shareholders, because the external financing is costly. By the increase of liquidity and leaving collateral value of company assets, the flexibility of the company from one side causes the increase of debt capacity and also decrease of the bankruptcy costs [8]. Kim et al. (1998) show that the investment in the current (or flexible) assets is costly, because the company can invest on the reproductive fixed assets instead of the current assets. Generally, when the uncertainty is increased in the decision-making, the value of the flexible assets is increased, too. Therefore, the changes at the debt levels reflect the moderations which can present information in regard of the financial flexibility of the companies [9].

\subsection{Financial Behavior}

\subsubsection{Investment Activities}

The successful performance of the companies can be effective in the creation of economic stimulus of the investors and ultimately the economic development of the country. This matter which is resulted in the more return for the companies and shareholders depends to the increase of investment activities for the production in the vast scale. The investment activities are most related to the getting and sale of long-term and short-term investments, tangible and intangible fixed assets and also the payment and reception of the facilities granted to the individual independent from the commercial unit except the employees [10]. According to the accounting standard No. 7 of International Accounting Standards Board (1993) and on the basis of aforesaid theoretical foundations and the carried out experimental studies, the following hypotheses can be mentioned [11]:

Hypothesis 1: the financial flexibility has positive and meaningful effect on the investment activities of the companies accepted in the stock exchange.

\subsubsection{Dividend Payment}

The company which pays the dividend at the present time can provide the recourses with the lowest cost by the reduction of dividend payment. So, it is expected that the companies which pay the dividend, hold few cash in comparison to the companies which don't pay the dividend [12]. So, it can be mentioned that:

Hypothesis 2: the financial flexibility has negative and meaningful effect on 
the ratio of dividend payment of the companies accepted in the stock exchange.

\subsubsection{Held Cash}

If the company has few cash, it would not be able to use its own investment opportunities or provide its own financial needs. So, this shortage would have negative effect on the company value. Although the existence of cash is important and necessary in the financial balance of all of the companies, but the level of importance of existence of this asset can be changed for different companies [13]. The existence of extra cash for a company can be considered ambiguous point for the market, because it can have either positive aspects or negative ones. Holding the extra cash in the companies from the market can be sign of this matter that these kinds of companies enjoy lower risk, because they have more capacity in encounter to the future probable financial problems. On the other side, the existence of extra cash in the companies can have negative effect on the performance of companies by creating the agency problems for them [14]. Mikkelson \& Partch (2003), in their research, revealed that the companies which hold higher level of cash, show better performance, too. They believed that there is no optimal level of cash for the company and the performance of companies is increased by the increase of level of cash holding [15]. So, the extra holding of the cash can be sign of absence of proficient allocation of the recourses and impose some costs on the company [16]. So it can be said:

Hypothesis 3: the financial flexibility has positive and meaningful effect on the amount of cash holding of the companies accepted in the stock exchange.

\subsubsection{Value of Accepted Companies}

Most of the present accounting systems neglect the increasing role and importance of the intellectual property right and the knowledge in the novel era organizations and are unable to evaluate the actual value of the assets in their calculations. In other words, the financial statements have many restrictions in the explanation of the actual value of the companies. In determining the company value, this is the investor that markets the stock exchange of the companies and wants to know the market value of these exchanges. If a company wants to maximize the shareholders' wealth, it should determine its purposes in the decision-makings in such a way that it increases the shareholders' demand for purchasing stocks and the other papers of the company. These kinds of demands would be resulted in the increase of price of that stock exchange in the market. The increase of value of the natural stock of the company is one of the ways to increase the wealth of the shareholders. So, the important matter which should be noticed is that the managers can pay attention to the variables and factors which are attracted by the shareholders in the process of determining the value of stock exchange [17]. So, the following hypothesis can be mentioned:

Hypothesis 4: the financial flexibility has positive and meaningful effect on the value of companies accepted in the stock exchange. 


\section{Research Method}

\subsection{Kind of Method and Purpose}

The present research is an applied descriptive, correlational study. The QuasiExperimental-Expost Facto method has been applied for collecting data.

\subsection{Population and Sample}

The statistic population of the present research is all the companies accepted in Tehran stock exchange. Due to the quality and facility of access to the financial statements and other needed information of the companies to study and calculate the various examined indexes, the years 2009 to 2015 were considered as the study period. The statistic sample was selected by the use of systematic deletion that after the execution of restrictions of this method, 100 qualified companies was selected as the sample volume.

\subsection{Collection of Data}

In the present research, at first the desk and credit studies have been applied for collecting the needed data and information that on this basis, the theoretical foundation and literature review were collected by the use of Persian and Latin expert magazines and books. Then, the data needed for testing the research hypotheses were extracted by reference to the financial statements and explaining notes of the selected companies, reports of board of directors, $\mathrm{CD}$, pictorial and statistic archive of Tehran stock exchange, website of stock exchange and also the Tadbir Pardaz and Rahavard Novin software.

\subsection{Data Analysis}

The econometric data panel and Eviews 9 were applied for testing the hypotheses of this research. The Chaw test has been applied to recognize whether the Panel method or the Pool method has been efficient in the assessment of the model. Also, the Hausman model was used to compare the efficiency of fixed effects model with the random effects model to determine a proper method for the assessment of the model. After execution of the recent tests and determining the path of estimation of the regression models, the research hypotheses were evaluated by the assessment of the mentioned models.

\subsection{Evaluation of Variables}

The following regression models are used for testing the research hypotheses [18]:

$$
\begin{aligned}
\text { LEVit }= & \beta 1 \text { LEVit }-1+\beta 2 \text { Industry Leverageit }-1 \\
& +\beta 2 \text { MTBit }-1+\beta 3 \text { Sizeit }-1+\beta 4 \text { Tangibilityit }-1 \\
& +\beta 5 \text { Profitabilityit }-1+\beta 6 \text { Inflationt }-1 \\
& + \text { Firm fixed effects }+ \text { Year fixed effects }+ \text { Uit }
\end{aligned}
$$




$$
\begin{aligned}
& L E V i t=1 L E V i t-1+\beta 1 \text { Industry Leverageit }-1+\beta 2 M T b_{i t-1} \\
& +\beta 3 \text { Sizeit }-1+\beta \text { TTangibilityit }-1+\beta 5 \text { Profitability }_{i t-1} \\
& +\beta 6 \text { Inflationt }-1 \beta 7 \text { Cashit }-1+\beta 8 \text { Maturityit }-1 \\
& +\beta 9 \text { Dividendsit }-1+\beta 10 \text { Taxit }-1+\beta 11 \text { Ndtsit }-1 \\
& +\beta \text { Firm fixed effects }+ \text { Year fixed effects }+ \text { Uit } \\
& \text { Investment activityit } \\
& =\beta 0 i+\beta 1 \text { Financial Flexibilityi }+\beta 2 \text { Financial Flexibilityi } \\
& \times \text { Cash flowit }-1+\beta \text { 3iFinancial Flexibilityi } \times \text { Crisist } \\
& +\beta 4 \text { iFinancial Flexibilityi } \times \text { Cash flowit }-1 \\
& \times \text { Crisist }+\beta 5 i X i t-1+\ldots t Y t \text { Yearit }+_{-} j_{-} j \text { Indj }+\varepsilon i t \\
& \text { Equity payout ratioit } \\
& =\beta 0 i+\beta 1 \text { Financial Flexibilityi }+\beta 2 \text { Financial Flexibilityi } \times \text { crisist } \\
& +\beta 3 i X i t-1+{ }_{-} t Y t \text { Yearit }+_{-} j_{-} j \text { Indj }+\varepsilon i t \\
& \text { cashit }=\beta 0 i+\beta 1 \text { Financial Flexibilityi }+\beta 2 i \text { Financial Flexibilityi } \times \text { Crisist } \\
& +\beta 3 i X i-1+\ldots i Y t \text { Yeari }+_{-} j_{-} j n d j+\varepsilon i t \\
& \times \text { Crisist }+\beta 3 i X i t-1+\_t Y t \text { Yearit }+_{-} j_{-} j n d j+\varepsilon i t
\end{aligned}
$$

According to the models, the companies which show a negative deviation between the actual and anticipated leverages are regarded as the companies which have not used the debt capacity. Similar to the study done by Marchica and Mora (2010), it needs at least three consecutive years of unused debt capacity for the company before categorizing it as the financial flexibility [19]. Simple univariate comparisons of firm characteristics suggest that financially flexible firms are more profitable and have a higher sales growth rate than never financially flexible firms. Financially flexible firms also have higher levels of cash holdings and lower leverage ratios. In addition, financially flexible firms have higher levels of capital expenditures [18]. The calculated financial flexibility is presented by the abbreviation FF1that means the primary evaluation of the financial flexibility used in this study. Specially, the FF1 is a virtual variable ( $0 \& 1)$. It would be 1 when the company does not use the debt capacity at least for three consecutive years, otherwise it would be zero. In Table 1, the operational definition of the research variables is presented according to the study by Yung et al. (2015) [18].

\section{Research Findings}

The results of findings of the Pearson Correlational Test between the variables reveal that the level of significance is more than $0 / 05$. So, there is no probability for the existence of co-linearity in the regression model.

\section{Study of Research Models}

According to Table 2, the level of significance of Chaw test in each of 6 studied equations has been calculated lower than $\alpha-0 / 05$. So, the possibility of the assessment of the models is certified $95 \%$ by the use of Panel model. 
Table 1. Definition of variables in recourse regression models.

\begin{tabular}{|c|c|}
\hline Variable & Definition \\
\hline FF1 & $\begin{array}{l}\text { The financial flexibility calculated in this paper is the company with financial } \\
\text { flexibility that has not used the debt capacity at least for three consecutive years }\end{array}$ \\
\hline LEV & Financial leverage: total debts to total assets ratio \\
\hline MTB & $\begin{array}{l}\text { market to book ratio, calculated as the book value of the assets plus value } \\
\text { of stock market minus book value of stock divided by book value of assets }\end{array}$ \\
\hline Size & Logarithm of total assets of company \\
\hline Tangibility & Fixed assets to total assets ratio \\
\hline Profitability & Profit obtained from extraordinary items divided by total assets \\
\hline Inflation & Amount of yearly inflation obtained from global bank \\
\hline $\mathrm{CF}$ & Cash flow of the companies \\
\hline IA & Investment activity \\
\hline EPR & Company payments to total assets ratio \\
\hline CASH & Amount of cash holding of company \\
\hline CRISIS & $\begin{array}{l}\text { The financial crisis which is a virtual variable and is } \\
1 \text { for the years } 2009 \text { and } 2010 \text { and otherwise it is zero }\end{array}$ \\
\hline YEAR & Year \\
\hline IND & Industry \\
\hline MATURE & Debt payable after one years to total debts \\
\hline DIVIDEND & Amount of dividend profit \\
\hline TAX & Amount of tax paid by company \\
\hline NDTS & Depreciation to total assets ratio \\
\hline
\end{tabular}

Table 2. Results of chaw test for regression models.

\begin{tabular}{lcccc}
\hline & $\begin{array}{c}\text { Statistic } \\
\text { of test }\end{array}$ & $\begin{array}{c}\text { Degrees } \\
\text { of freedom }\end{array}$ & $\begin{array}{c}\text { Significance } \\
\text { level }\end{array}$ & Result \\
\hline Regression Model 1 & 6.12 & $(95 \& 493)$ & 0.000 & Use of Panel model \\
Regression Model 2 & 2.26 & $(95 \& 488)$ & 0.000 & Use of Panel model \\
Regression Model 3 & 24.01 & $(95 \& 594)$ & 0.000 & Use of Panel model \\
Regression Model 4 & 24.08 & $(95 \& 596)$ & 0.000 & Use of Panel model \\
Regression Model 5 & 43.44 & $(99 \& 596)$ & 0.000 & Use of Panel model \\
Regression Model 6 & 7.49 & $(99 \& 596)$ & 0.000 & Use of Panel model \\
\hline
\end{tabular}

With regard to this matter that the hypothesis "the zero of Chaw test based on equality of y-intercept" was rejected. Then, the Hausman Test is applied for the recognition of existence of fixed effects or random effects. According to Table 3, the level of significance of the Hausman Test for each of 5 equations has been calculated more than prob-0/05. Therefore, the Hausman Test in these 4 equations estimates the use of random effects. 
At first, the results of estimation of regression model by the use of Panel method and GMM method in Table 4.

The results of estimation of second regression model by the Panel method and the GMM method have been presented in Table 5.

The estimation of third model by the use of random effects has been presented in Table 6.

The estimation of forth model by the use of random effects has been presented in Table 7.

The estimation of fifth model by the use of random effects has been presented in Table 8.

The estimation of sixth model by the use of random effects has been presented in Table 9.

Table 3. Results of Hausman test for regression models.

\begin{tabular}{lcccc}
\hline & $\begin{array}{c}\text { Statistic } \\
\text { of test }\end{array}$ & $\begin{array}{c}\text { Degrees } \\
\text { of freedom }\end{array}$ & $\begin{array}{c}\text { Significance } \\
\text { level }\end{array}$ & Result \\
\hline Regression Model 1 & 0.000 & 7 & 1.00 & Use of Random Effects \\
Regression Model 2 & 3.06 & 12 & 0.99 & Use of Random Effects \\
Regression Model 3 & 0.000 & 6 & 1.00 & Use of Random Effects \\
Regression Model 4 & 0.000 & 4 & 1.00 & Use of Random Effects \\
Regression Model 5 & 0.000 & 4 & 1.00 & Use of Random Effects \\
Regression Model 6 & 0.000 & 4 & 1.00 & Use of Random Effects \\
\hline
\end{tabular}

Table 4. Results of fitting regression model (1) (GMM method).

\begin{tabular}{|c|c|c|c|c|c|}
\hline \multicolumn{6}{|c|}{ Dependent variable-financial leverage } \\
\hline Independent variables & VARIABLE & $\begin{array}{l}\text { Regression } \\
\text { coefficient }\end{array}$ & $\begin{array}{l}\text { Standard } \\
\text { deviation }\end{array}$ & $\begin{array}{l}\text { Statistic } \\
\text { of } t \text {-Test }\end{array}$ & $\begin{array}{c}\text { Level of } \\
\text { significance }\end{array}$ \\
\hline Equation constant $(\alpha)$ & $\mathrm{C}$ & $-0 / 0008$ & $0 / 08$ & $-0 / 01$ & $0 / 99$ \\
\hline $\begin{array}{l}\text { Financial leverage } \\
\text { of last period }\end{array}$ & $\operatorname{LEV}(-1)$ & $0 / 22$ & $0 / 05$ & $4 / 38$ & $0 / 000$ \\
\hline $\begin{array}{c}\text { Financial leverage } \\
\text { of industry }\end{array}$ & ILEV & $-0 / 27$ & $0 / 12$ & $-2 / 17$ & $0 / 03$ \\
\hline Market to book ratio & MTB & $-1 / 52$ & $0 / 43$ & $-3 / 46$ & $0 / 000$ \\
\hline Company size & SIZE & $0 / 01$ & $0 / 009$ & $1 / 80$ & $0 / 07$ \\
\hline $\begin{array}{l}\text { Fixed assets to } \\
\text { total assets ratio }\end{array}$ & TANG & $0 / 07$ & $0 / 02$ & $2 / 85$ & $0 / 004$ \\
\hline $\begin{array}{l}\text { Profit before extraordinary } \\
\text { items divided by total assets }\end{array}$ & PROF & $0 / 21$ & $0 / 04$ & $4 / 28$ & $0 / 000$ \\
\hline inflation & INFLATION & $-3 / 20 * \mathrm{e}^{-5}$ & $0 / 0002$ & $-0 / 11$ & $0 / 90$ \\
\hline Moderate & ermination & icient $-0 / 5$ & atistic D. & $2 / 14$ & \\
\hline
\end{tabular}


Table 5. Results of fitting regression model (2) (GMM method).

\begin{tabular}{cccccc}
\hline \multicolumn{5}{c}{ Dependent variable-financial leverage } & \\
\hline Independent variable & VARIABLE & $\begin{array}{c}\text { Regression } \\
\text { coefficients }\end{array}$ & $\begin{array}{c}\text { Standard } \\
\text { deviation }\end{array}$ & $\begin{array}{c}\text { Statistic } \\
\text { of } t \text {-test }\end{array}$ & $\begin{array}{c}\text { Level of } \\
\text { significance }\end{array}$ \\
\hline Equation constant $(\alpha)$ & C & $-0 / 04$ & $0 / 37$ & $-1 / 04$ & $0 / 29$ \\
Financial leverage of last period & LEV $(-1)$ & $-7 / 73{ }^{*} \mathrm{e}^{-5}$ & $0 / 001$ & $-0 / 04$ & $0 / 96$ \\
Financial leverage of industry & ILEV & $-0 / 003$ & $0 / 002$ & $-1 / 15$ & $0 / 24$ \\
Market to book ratio & MTB & $-1 / 45$ & $0 / 43$ & $3 / 33$ & $0 / 000$ \\
Company size & SIZE & $-0 / 001$ & $0 / 0006$ & $-2 / 27$ & $0 / 02$ \\
Fixed assets to total assets ratio & TANG & $0 / 001$ & $0 / 007$ & $-1 / 51$ & $0 / 13$ \\
Profit before extraordinary & PROF & $0 / 004$ & $0 / 002$ & $1 / 98$ & $0 / 04$ \\
items divided by total assets & & & & & \\
Inflation & INFLATION & $-0 / 99$ & $0 / 001$ & $-610 / 61$ & $0 / 000$ \\
Amount of cash holding & CASH & $-0 / 002$ & $0 / 009$ & $-0 / 23$ & $0 / 81$ \\
Company mature & MATURE & $0 / 002$ & $0 / 001$ & $1 / 47$ & $0 / 14$ \\
Dividend profit & DIVIDEND & $-0 / 03$ & $0 / 05$ & $-0 / 52$ & $0 / 59$ \\
Tax & TAX & $2 / 98$ & $0 / 004$ & $610 / 57$ & $0 / 000$ \\
Depreciation to total assets ratio & NDTS & $0 / 86$ & $0 / 87$ & $0 / 99$ & $0 / 32$
\end{tabular}

Moderated determination coefficient-0/69 statistic D.W-2/32

Table 6. Results of fitting of third regression model (random effects).

\begin{tabular}{|c|c|c|c|c|c|}
\hline \multicolumn{6}{|c|}{ Dependent variable-investment activity } \\
\hline Independent variable & VARIABLE & $\begin{array}{l}\text { Regression } \\
\text { coefficients }\end{array}$ & $\begin{array}{l}\text { Standard } \\
\text { deviation }\end{array}$ & $\begin{array}{l}\text { Statistic } \\
\text { of } t \text {-test }\end{array}$ & $\begin{array}{c}\text { Level of } \\
\text { significance }\end{array}$ \\
\hline Equation constant $(\alpha)$ & $\mathrm{C}$ & $-37 / 88$ & $23 / 82$ & $-1 / 59$ & $0 / 11$ \\
\hline Financial flexibility & FF1 & $0 / 44$ & $0 / 13$ & $+3 / 36$ & $0 / 000$ \\
\hline Financial flexibility ${ }^{*}$ cash flow & $\mathrm{FF} 1 * \mathrm{CF}$ & $-0 / 31$ & $0 / 04$ & $-6 / 28$ & $0 / 000$ \\
\hline Financial flexibility ${ }^{*}$ crisis & $\mathrm{FF} 1{ }^{*} \mathrm{CRISIS}$ & $0 / 39$ & $0 / 14$ & $2 / 75$ & $0 / 005$ \\
\hline $\begin{array}{c}\text { Financial flexibility } \\
\text { cash flow }{ }^{*} \text { crisis }\end{array}$ & $\begin{array}{l}\mathrm{CF}^{*} \mathrm{FF} 1{ }^{*} \\
\text { CRISIS }\end{array}$ & $-0 / 24$ & $0 / 04$ & $-5 / 56$ & $0 / 000$ \\
\hline Year & YEAR & $0 / 02$ & $0 / 01$ & $1 / 60$ & $0 / 10$ \\
\hline Industry & IND & $0 / 01$ & $0 / 01$ & $1 / 01$ & $0 / 31$ \\
\hline \multicolumn{6}{|c|}{ Statistic of test F-26/04 level of significance-0/000. } \\
\hline
\end{tabular}

Table 7. Results of fitting of fourth regression model (4) (random effects).

\begin{tabular}{cccccc}
\hline \multicolumn{5}{c}{ Dependent variable-payment ratio } \\
\hline Independent variables & VARIABLE & $\begin{array}{c}\text { Regression } \\
\text { coefficients }\end{array}$ & $\begin{array}{c}\text { Standard } \\
\text { deviation }\end{array}$ & $\begin{array}{c}\text { Statistic of } \\
t \text {-test }\end{array}$ & $\begin{array}{c}\text { Level of } \\
\text { significance }\end{array}$ \\
\hline Equation constant $(\alpha)$ & C & $-21 / 62$ & $12 / 93$ & $-1 / 67$ & $0 / 09$ \\
Financial flexibility & FF1 & $0 / 21$ & $0 / 06$ & $+3 / 49$ & $0 / 000$ \\
Financial flexibility ${ }^{*}$ crisis & FF1 ${ }^{*}$ CRISIS & $0 / 39$ & $0 / 07$ & $2 / 23$ & $0 / 02$ \\
Year & YEAR & $0 / 02$ & $0 / 009$ & $1 / 67$ & $0 / 09$ \\
Industry & IND & $0 / 01$ & $0 / 006$ & $1 / 66$ & $0 / 09$
\end{tabular}

Statistic of test F-25/30 Level of significance-0/000.

Moderated determination coefficient-0/62 statistic D.W-1.54 
Table 8. Results of fitting of fourth regression model (5) (random effects).

\begin{tabular}{cccccc}
\hline \multicolumn{6}{c}{ Dependent variable-payment ratio } \\
\hline Independent variables & VARIABLE & $\begin{array}{c}\text { Regression } \\
\text { coefficients }\end{array}$ & $\begin{array}{c}\text { Standard } \\
\text { deviation }\end{array}$ & $\begin{array}{c}\text { Statistic } \\
\text { of } t \text {-test }\end{array}$ & $\begin{array}{c}\text { Level of } \\
\text { significance }\end{array}$ \\
\hline Equation constant $(\alpha)$ & C & $-1 / 83$ & $-1 / 35$ & $-1 / 35$ & $0 / 17$ \\
Financial flexibility & FF1 & $0 / 01$ & $0 / 01$ & $1 / 12$ & $0 / 26$ \\
Financial flexibility * crisis & FF1 * CRISIS & $0 / 01$ & $0 / 008$ & $1 / 97$ & $0 / 04$ \\
Year & YEAR & $0 / 001$ & $0 / 0009$ & $1 / 40$ & $0 / 16$ \\
Industry & IND & $-0 / 004$ & $0 / 003$ & $-1 / 26$ & $0 / 20$ \\
\multicolumn{5}{c}{$\begin{array}{l}\text { Statistic of test F-33/37 Level of significance-0/000. } \\
\text { Moderated determination coefficient-0/50 statistic D.W-2/30 }\end{array}$} \\
\hline
\end{tabular}

Table 9. Results of fitting of fourth regression model (6) (random effects).

\begin{tabular}{cccccc}
\hline \multicolumn{7}{c}{ Dependent variable-payment ratio } \\
\hline Independent variables & Variable & $\begin{array}{c}\text { Regression } \\
\text { coefficients }\end{array}$ & $\begin{array}{c}\text { Standard } \\
\text { deviation }\end{array}$ & $\begin{array}{c}\text { Statistic } \\
\text { of } t \text {-test }\end{array}$ & $\begin{array}{c}\text { Level } \\
\text { of significance }\end{array}$ \\
\hline Equation constant $(\alpha)$ & C & $-3505 / 2$ & $911 / 6$ & $-3 / 84$ & $0 / 000$ \\
Financial flexibility & FF1 & $19 / 97$ & $5 / 41$ & $3 / 68$ & $0 / 000$ \\
Financial flexibility * crisis & FF1 * CRISIS & $21 / 74$ & $5 / 42$ & $4 / 006$ & $0 / 04$ \\
Year & YEAR & $2 / 52$ & $0 / 65$ & $3 / 86$ & $0 / 000$ \\
Industry & IND & $-4 / 06$ & $1 / 86$ & $-2 / 18$ & $0 / 02$ \\
& Statistic of test F-33/37 Level of significance-0/000. & \\
\hline
\end{tabular}

\section{Discussion and Conclusions}

It was expressed in this research that the financial flexibility has positive and meaningful effect on the financial behavior of the companies accepted in the stock exchange. But in the other cases, it can be mentioned that the financial flexibility does not have negative and meaningful effect on the dividend payout ratio, amount of cash holding and the value of companies accepted in the stock exchange. This result does not conform to the results obtained from studying the basic paper and just the impressionability of financial behavior from the financial behavior of the companies corresponds with the result of study done by Yung et al., (2015) [18]. Then, the results of the other studies were compared with present research. Clark (2010) studies the effect of the financial flexibility on the decisions of capital structure. He uses the final value of the cash as a criterion for the final value of the flexibility [20]. The results of present research reveal when the final value of the flexibility is studied in relation to the decisions of the capital structure, the other variables effective on the capital structure lose their importance considerably and in better words, the flexibility is the most important and effective factor in the capital structure. Also, Clark shows that the companies with higher final value of flexibility are more inclined to save their 
own debt capacity for the next years and this result corresponds with the results of the study done by DeAngelo and Whited (2010) [21]. Also, the companies with higher final value of flexibility are more inclined to increase the capital in order to provide their needed recourses by spreading the debt that this kind of financing has just aimed to maintain the debt capacity.

Triantis and Gamba (2009) measured the value of the flexibility in a research. They revealed that the value of the flexibility depends to the cost of external financing, tax rate of the company, cost of opportunity of cash holding, opportunities of potential development of the company and being returnable of the capital. They showed that the companies which have financial problems should borrow and lend simultaneously [3]. Byoun (2007) studied the relation between the financial flexibility, leverage and company size. He concluded that the small companies have lower leverage ratio which is for the reason that they provide their recourses by the increase of internal capital (according to flexibility hypothesis). Byoun argued that the small companies keep their debt and leverage ratio at lower level so that the company flexibility will be retained. The debt contracts often have the restrictive conditions for the investment and debt ratios that can have hard effect especially for the small and developing companies. The internal financing by the shareholders permits the companies to increase the amount of their cash holding without liquidation of the company flexibility. Byoun rejects the results obtained from the previous researches based on the positive relation between the company size, leverage and flexibility. He expresses that there is a reverse relation between the financial leverage and the flexibility [4].

\section{Applied Suggestions}

According to the meaningfulness of effect of the financial flexibility on the financial behavior, dividend payout ratio and amount of cash holding in companies of Tehran stock exchange, it is suggested to the government to provide the situation by granting the permits to the monetary organs of the country such as state bank and the other banks with the presentation of debt instruments in a full-scale form of the activity of the companies and flexibility of financial conditions of the companies, because the matter increases the development of the stock market according to the results obtained from this research. In addition to attention to the previous purposes and policies of the company for the purpose of getting profit and cash flow, the investors consider in their decision-makings, the future viewpoints of the commercial units in the mechanization, development and replacement of the apparatus and also the long-term and short-term investments which are the generator of profitability and liquidity in the commercial units to anticipate the operational cash flows, price and ultimately the extraordinary output of the stock. The shareholders in the companies with higher flexibility can have better opportunities for the future development and also the income derived from their own investments.

The investors should ask the companies for the exact statistic of the cash and 
the liquidity accumulation to select the companies with higher flexibility for the investment, in addition to the prevention of management of profit in the companies. It is suggested to the investors to invest in the companies which work more in the market, because by the increase of free cash flow of the company, the company potential and flexibility for the comprehensive presentation in the market are increased and this results in the more financial flexibility of the company. The investors should pay attention to the financial assets of the company and with regard to this matter that the accumulation of liquidity level increases the flexibility of the company, the companies with more asset value are proper for the investments. So, it is suggested to the investors to expect more flexibility by investing in the companies with higher asset value and have better opportunities for the profitability of their investment.

\section{References}

[1] Byoun, S. (2008) Financial Flexibility and Capital Structure Decision. SSRN Working Paper.

[2] Heath, L.C. (1978) Financial Reporting and the Evaluation of Solvency. American Institute of Certified Public Accountants, New York.

[3] Gamba, A. and Triantis, A. (2008) The Value of Financial Flexibility. The Journal of Finance, 63, 263-296. https://doi.org/10.1111/j.1540-6261.2008.01397.x

[4] Byoun, S. (2007) Financial Flexibility, Leverage, and Firm Size. Waco, TX. January.

[5] Heaton, J. (2002) Managerial Optimism and Corporate Finance. Journal of Financial Management, 31, 33-45.

[6] De Jong, A., Verbeek, M. and Verwijmeren, P. (2012) Does Financial Flexibility Reduce Investment Distortions? Journal of Financial Research, 35, 243-259. https://doi.org/10.1111/j.1475-6803.2012.01316.x

[7] Graham, J.R. and Harvey, C.R. (2001) The Theory and Practice of Corporate Finance: Evidence.

[8] Mauer, D.C. and Triantis, A.J. (1994) Interaction of Corporate Financing and Investment Decisions: A Dynamic Framework. Journal of Finance, 49, 1253-1277. https://doi.org/10.1111/j.1540-6261.1994.tb02453.x

[9] Kim, C.S., Mauer, D. and Sherman, A.E. (1998) The Determinants of Corporate Liquidity.

[10] International Accounting Standards Board (2006) Accounting Standards, Accounting Organizations.

[11] IASB (1993) Statement of Cash Flows. International Accounting Standards, No. 7.

[12] Ferreira, M. and Vilela, A. (2004) Why Do Firms Hold Cash? Evidence from EMU Countries. European Financial Management, 10, 295-319. https://doi.org/10.1111/j.1354-7798.2004.00251.x

[13] MeshkiMiavgi, M. and ElahiRoodposhti, S. (2015) Study of Effect of Conservatism on Market Value of Cash Held. Experimental Researches of Accounting, 4th Period, No. 1, 23-43.

[14] Jensen, M. (1986) Agency Costs of Free Cash Flow, Corporate Finance, and Takeovers. American Economic Review, 76, 323-329.

[15] Mikkelson, W. and Partch, M. (2003) Do Persistent Large Cash Reserves Hinder Performance. Journal of Financial and Quantitative Analysis, 38, 275-294. 
https://doi.org/10.2307/4126751

[16] Ozkan, A. and Ozkan, N. (2004) Corporate Cash Holding. An Empirical Investigation of UK Companies. Journal of Banking\& Finance, 28, 2103-2134.

https://doi.org/10.1016/j.jbankfin.2003.08.003

[17] Rahmani, A., et al. (2012) Effect of Financial Flexibility on Amount of Investment and Value-Creation. Magazine of Accounting Developments of Shiraz University, 4th Period, No. 2, Autumn \& Winter, 53-76.

[18] Yung, K., Li, D. and DeQing, J.Y. (2015) The Value of Corporate Financial Flexibility in Emerging Countries. Journal of Multinational Financial Management, 32-33, 25-41. https://doi.org/10.1016/j.mulfin.2015.07.001

[19] Marchica, M.T. and Mura, R. (2010) Financial Flexibility, Investment Ability, and Firm Value: Evidence from Firms with Spare Debt Capacity. Financial Management, 39, 1339-1368. https://doi.org/10.1111/j.1755-053X.2010.01115.X

[20] Clark, B.J. (2010) The Impact of Financial Flexibility on Capital Structure Decisions: Some Empirical Evidence. https://doi.org/10.2139/ssrn.1499497

[21] DeAngelo, H., DeAngelo, L. and Whited, T.M. (2010) Capital Structure Dynamics and Transitory Debt. http://ssrn.com/abstract=1262464 